\title{
Outcome after acute osteomyelitis in preterm infants
}

\author{
J B Williamson, C S B Galasko, M J Robinson
}

\begin{abstract}
Eight cases of skeletal infection in preterm infants were studied. All the infants were systemically unwell, with polymorpholeucocytosis. Diagnosis was by blood culture, and any radiographic changes were apparent at the time of presentation. Infection was often multifocal, with sites around the knee being most commonly affected. Staphylococcus aureus was the pathogen isolated in six of the eight cases; in these treatment with fusidic acid was effective and well tolerated, even at doses that were less than the recommended therapeutic minimum.
\end{abstract}

Even with prompt diagnosis and aggressive treatment orthopaedic sequelae are common.

Acute osteomyelitis is an uncommon but important neonatal infection. In this paper we report the methods of treatment and results in eight preterm patients with acute osteomyelitis.

\section{Patients and methods}

Eight preterm infants with skeletal infections were admitted to our neonatal intensive care unit between 1982 and 1988; their salient clinical features are summarised in the table.

All eight children were preterm, being born between 25 and 33 (mean 29.4) weeks' gestation. All were admitted to the neonatal unit for treatment of the consequences of prematurity.

Four of the eight had umbilical arterial lines in place at the time of the development of the septic episode. In each patient sepsis was suspected on clinical grounds before the presentation of any localising signs. All eight patients had considerably increased white cell counts. In all eight the clinical presence of infection prompted the performance of a 'septic screen'. Organisms were isolated from the primary blood cultures in each patient and in addition three patients grew organisms from other sites-the umbilical stump, cerebrospinal fluid, and an infected intravenous cannula. The pathogens isolated were Staphylococcus aureus in six of the eight patients, and group $G \beta$ haemolytic streptococcus and Candida albicans in the remaining two.

There was a delay (mean 2.9 days, range 0 8)-especially early in the series-between presentation with systemic signs and the definitive diagnosis of skeletal sepsis. In the most recent four patients the definitive diagnosis was made on the day of presentation.

Five of the eight patients were treated by some form of drainage procedure (aspiration, $\mathrm{n}=3$; open surgical drainage, $\mathrm{n}=2$ ). All patients were treated with sodium fusidate, $20 \mathrm{mg} / \mathrm{kg}$ / day, initially intravenously (for a mean of 11 days, range 7-21), and orally when they were tolerating oral feeds (for a mean of 22 days, range 21-27). Treatment lasted for a mean of 32 days (range 28-42). An additional antistaphylococcal antibiotic was used when appropriate. Initially serum concentrations of fusidic acid were measured by high performance liquid chromatography. Despite clinical improvement in all eight patients, therapeutic concentrations of fusidic acid were not achieved with either oral or parenteral treatment. Serum bactericidal titres were also below the recommended therapeutic minimum. The duration of treatment was determined by each infant's clinical progress, and in one patient it continued after discharge from hospital.

Six patients were reviewed in the follow up clinic. The recent progress of the two nonattenders was obtained from their general practitioners.

\section{Results}

The patients had been followed up for between 2 years 2 months and 6 years since their infections. Two of the eight children failed to attend the specially arranged follow up clinic, but had normal musculoskeletal examinations when last seen in the orthopaedic clinic at 3.5 years of age.

Skeletal sepsis seemed to have been abolished by treatment in all patients. At the time of follow up no patient had developed chronic osteomyelitis.

In six of the eight patients the radiographic appearance was diagnostic of skeletal infection. The presence of radiographic changes did not seem to be related to the length of time that sepsis had been present, as there were changes on the radiographs of patients taken on the day that they had presented with systemic upsets. Two patients had normal radiographs throughout, and in two (one of whom had a diagnostic radiograph) ${ }^{99 m} \mathrm{Tc}$ labelled diphosphonate scintigraphy was carried out; both scintigrams were normal.

Long term orthopaedic sequelae, such as discrepancies in limb length, angular deformity, and joint stiffness developed in five of the eight patients. Progressive discrepancy in limb length was the commonest long term problem $(n=5)$, with joint destruction and axial deformity each occurring in one patient. One patient (case 7) has had his deformity corrected surgically. Limb lengthening is planned for the same patient in the near future. 
Clinical details of eight neonates with acute osteomyelitis

\begin{tabular}{|c|c|c|c|c|c|c|c|}
\hline $\begin{array}{l}\text { Case } \\
\text { No }\end{array}$ & $\begin{array}{l}\text { Birth weight } \\
(\mathrm{g})\end{array}$ & $\begin{array}{l}\text { Gestation } \\
\text { (weeks) }\end{array}$ & Age at presentation & Clinical features & Bacteriology & Treatment & Outcome \\
\hline 1 & 1230 & 29 & $\begin{array}{l}\text { Day } 5 \text { systemic upset: } \\
\text { blood culture } \\
\text { Day } 11 \text { left distal femur } \\
\text { Day } 13 \text { right distal femur } \\
\text { Day } 19 \text { left distal tibia }\end{array}$ & $\begin{array}{l}\text { Apnoea } \\
\text { Swollen knee } \\
\text { White cell count } \\
22000 \times 10^{9} / 1 \\
\text { Radiograph normal } \\
\text { Scintigram normal }\end{array}$ & $\begin{array}{l}S \text { aureus in blood and } \\
\text { aspirate }\end{array}$ & $\begin{array}{l}\text { Aspiration; fusidic acid } \\
\text { and erythromicin }\end{array}$ & $\begin{array}{l}\text { Full movements; } \\
2 \mathrm{~cm} \text { shortening at } \\
6 \text { years of age }\end{array}$ \\
\hline 2 & 1800 & 32 & $\begin{array}{l}\text { Day } 10 \text { systemic upset: } \\
\text { blood culture } \\
\text { Day } 13 \text { left proximal } \\
\text { femur }\end{array}$ & $\begin{array}{l}\text { White cell count } \\
25000 \times 10^{9} / 1 \\
\text { Radiograph hip: } \\
\text { dislocation, gross } \\
\text { osteomyelitis }\end{array}$ & $\begin{array}{l}S \text { aureus in blood and } \\
\text { aspirate }\end{array}$ & $\begin{array}{l}\text { Surgical drainage; fusidic } \\
\text { acid and erythromicin }\end{array}$ & $\begin{array}{l}\text { Decreased movement; } \\
3 \mathrm{~cm} \text { shortening at } \\
2.2 \text { years of age }\end{array}$ \\
\hline 3 & 1790 & 31 & $\begin{array}{l}\text { Day } 7 \text { systemic upset: } \\
\text { blood culture } \\
\text { Day } 9 \text { right distal femur }\end{array}$ & $\begin{array}{l}\text { White cell count } \\
45000 \times 10^{9} / 1 \\
\text { Radiograph: } \\
\text { osteomyelitis }\end{array}$ & $\begin{array}{l}S \text { aureus in blood and } \\
\text { aspirate }\end{array}$ & $\begin{array}{l}\text { Aspiration; fusidic acid } \\
\text { and flucloxacillin }\end{array}$ & $\begin{array}{l}\text { No sequelae at } \\
3 \text { years of age }\end{array}$ \\
\hline 4 & 1800 & 33 & $\begin{array}{l}\text { Day } 7 \text { systemic upset: } \\
\text { cerebrospinal fluid } \\
\text { and blood culture } \\
\text { Day } 19 \text { right distal femur } \\
\text { Day } 21 \text { right proximal } \\
\text { femur } \\
\text { Day } 21 \text { left proximal tibia }\end{array}$ & $\begin{array}{l}\text { White cell count } \\
29000 \times 10^{9} / 1 \\
\text { Radiograph: } \\
\text { osteomyelitis } \\
\text { Scintigram normal }\end{array}$ & $\begin{array}{l}S \text { aureus in blood and } \\
\text { cerebrospinal fluid }\end{array}$ & $\begin{array}{l}\text { No drainage; } \\
\text { flucloxacillin and } \\
\text { chloramphenicol, } \\
\text { followed by fusidic } \\
\text { acid }\end{array}$ & $\begin{array}{l}\text { No sequelae at } \\
3.5 \text { years of age }\end{array}$ \\
\hline 5 & 1560 & 31 & $\begin{array}{l}\text { Day } 15 \text { systemic upset: } \\
\text { blood culture } \\
\text { Day } 15 \text { right distal femur } \\
\text { Day } 17 \text { left proximal tibia }\end{array}$ & $\begin{array}{l}\text { Hot swollen knee } \\
\text { White cell count } \\
29000 \times 10^{9} / 1 \\
\text { Radiograph normal }\end{array}$ & $\begin{array}{l}S \text { aureus in blood and } \\
\text { aspirate }\end{array}$ & $\begin{array}{l}\text { Surgical drainage; } \\
\text { fusidic acid and } \\
\text { erythromicin }\end{array}$ & $\begin{array}{l}\text { No sequelae at } \\
3.5 \text { years of age }\end{array}$ \\
\hline 6 & 620 & 25 & $\begin{array}{l}\text { Day } 7 \text { systemic upset: } \\
\text { blood culture } \\
\text { left proximal femur }\end{array}$ & $\begin{array}{l}\text { Abdominal distension } \\
\text { White cell count } \\
30000 \times 10^{9} / 1 \\
\text { Radiograph: } \\
\text { osteomyelitis }\end{array}$ & $\begin{array}{l}S \text { aureus in blood and } \\
\text { aspirate }\end{array}$ & $\begin{array}{l}\text { Aspiration; fusidic acid } \\
\text { and flucloxacillin }\end{array}$ & $\begin{array}{l}\text { Full movement; } \\
1 \mathrm{~cm} \text { shortening at } \\
3.5 \text { years of age }\end{array}$ \\
\hline 7 & 800 & 26 & $\begin{array}{l}\text { Day } 19 \text { umbilical line } \\
\text { Day } 49 \text { left distal femur }\end{array}$ & $\begin{array}{l}\text { White cell count } \\
25000 \times 10^{9} / 1 \\
\text { Radiograph: } \\
\text { osteomyelitis }\end{array}$ & $\begin{array}{l}C \text { albicans in blood } \\
\text { and catheter tip }\end{array}$ & $\begin{array}{l}\text { No drainage; } \\
\text { amphotericin and } \\
\text { cefuroxime }\end{array}$ & $\begin{array}{l}30^{\circ} \text { Flexion deformity } \\
\text { at knee; } 8 \mathrm{~cm} \\
\text { shortening at } \\
6.5 \text { years of age }\end{array}$ \\
\hline 8 & 1100 & 28 & $\begin{array}{l}\text { Day } 10 \text { skin abscess } \\
\text { Day } 16 \text { right distal femur } \\
\text { Day } 16 \text { right proximal } \\
\text { femur }\end{array}$ & $\begin{array}{l}\text { White cell count } \\
23000 \times 10^{9} / 1 \\
\text { Radiograph: } \\
\text { osteomyelitis }\end{array}$ & $\begin{array}{l}\beta \text { haemolytic } \\
\text { streptococcus in pus } \\
\text { from skin abscess, } \\
\text { and from blood }\end{array}$ & $\begin{array}{l}\text { No drainage; fusidic acid } \\
\text { and penicillin }\end{array}$ & $\begin{array}{l}\text { No sequelae at } \\
3.5 \text { years of age }\end{array}$ \\
\hline
\end{tabular}

Case 7 had a candida infection of his umbilical line on day 16 that persisted. He became 'septic' on day 49 with a candida septicaemia and osteomyelitis. Case 8 had a skin infection on day 10, but did not become systemically unwell until day 16, when she had localising signs of skeletal sepsis.

The orthopaedic outcome was not related to the severity of initial infection, delay in making a definitive diagnosis, or the performance of surgical drainage.

\section{Discussion}

Osteomyelitis is an uncommon but important neonatal infection with a recognised morbidity and mortality. ${ }^{1}$ The definitive treatment and its duration has not yet been defined.

Osteomyelitis in well nourished infants born at full term seems to cause little in the way of systemic upset, ${ }^{23}$ but constitutional symptoms were much more of a feature in a series of Nigerian infants born at full term. ${ }^{1}$ Two of the four patients with osteomyelitis associated with umbilical catheter sepsis reported by Brill et al were systemically unwell, ${ }^{4}$ but two had no generalised features of sepsis. Only one of their babies who had systemic symptoms was preterm. All eight of our patients were preterm and all had systemic symptoms. We suggest that osteomyelitis in infants who are immunocompromised because of malnourishment or prematurity is much more likely to be accompanied by septicaemia and systemic upset. Multifocal disease occurred in four of our patients and this accords with the experience of other authors. ${ }^{5}$

Blood cultures from all our patients grew pathogens, and were helpful in deciding definitive antimicrobial treatment. When drainage procedures were carried out they served both to decompress and to aid diagnosis. Identical organisms were grown from the aspirate and the blood cultures. All patients treated without operation made good recoveries from their systemic upsets once treatment with antibiotics was started.

Other authors have reported the occurrence of bone and joint infection distal and ipsilateral to the tip of umbilical artery catheters, especially if vascular spasm accompanied its introduction. ${ }^{6}$ It was suggested that osteomyelitis associated with umbilical catheterisation may be avoided by adherence to a protocol incorporating strict asepsis and immediate removal of the catheter if there was vascular compromise. In our patients who had umbilical arterial catheterisation, the catheter tip was at $\mathrm{L} 4 / 5$, and there was no suggestion of vascular insufficiency. The distribution of the affected joints was not significantly different from that in the patients without umbilical catheters, and we do not think that umbilical arterial catheterisation was an important factor in the development of sepsis.

The presence of radiographic signs at presentation in neonates has not been noted previously to our knowledge, and may suggest that the infection had been present subclinically before presentation. The limited value of skeletal scintigraphy was commented on by Ash and Gilday. $^{\text {? }}$

The effectiveness and lack of serious side effects of fusidic acid in the treatment of staphylococcal neonatal osteomyelitis is well documented. ${ }^{89}$ The use of a second antistaphylococcal drug is essential to prevent the emergence of resistant strains. ${ }^{10}$ The fact that adult therapeutic concentrations or recommended bactericidal concentrations were never achieved 
despite considerable clinical improvement is interesting, and illustrates the difference between the in vivo and in vitro effects of drugs. It is a matter of orthopaedic tradition and dogma that long courses of antibiotic (usually six weeks) are used for skeletal infection. This does not seem to be necessary in preterm infants.

The distinction between septic arthritis and osteomyelitis is often difficult in infants. The epiphyseal circulation is derived from the same periarticular anastamoses as the metaphyseal circulation and this common circulation provides a pathway for the transphyseal spread of infection. It would therefore seem likely that the primary skeletal infection is metaphyseal osteomyelitis, but a secondary septic arthritis soon develops. The growth plate is surrounded by infected tissue and its blood supply, which is almost exclusively from the metaphyseal circulation, is compromised.

Most of the orthopaedic complications were the results of physeal damage by the septic process, with progressive discrepancy in limb length being caused by symmetrical physeal damage, and axial deformity being caused by asymmetrical physeal damage.

\section{CONCLUSIONS}

In preterm infants the clinical picture of acute osteomyelitis is different from that in babies born at full term and in older children, in that systemic upset and pronounced polymorpholeucocytosis are invariably present. Any radiographic changes were apparent at the time of presentation.

It is important to keep the possibility of skeletal sepsis in mind, and any child with a clinical diagnosis of sepsis, especially staphylococcal septicaemia without an obvious focus, should have the hips and knees carefully examined and radiographed.

Treatment with sodium fusidate and a second antistaphylococcal drug, initially given intravenously, achieved satisfactory antimicrobial effect, although bony sequelae were common.

1 Omene JA, Odita JC, Okolo AA. Neonatal osteomyelitis in Nigerian infants. Pediatr Radiol 1984;14:318-22.

2 Fox L, Sprunt K. Neonatal osteomyelitis. Pediatrics 1978;62 535-42.

3 Weissberg EG, Smith AL, Smith DH. Clinical features of acute osteomyelitis. Pediatrics 1974;53:505-10.

4 Brill PW, Winchester P, Krauss AN, Symchych P. Osteomyelitis in a neonatal unit. Radiology 1979;131:83-7.

5 Mok PM, Reilly BJ, Ash JM. Osteomyelitis in the neonate.

Radiology 1982;145:677-82.
$6 \mathrm{Lim}$ MO, Gresham EL, Franken EA, Leake RD. Osteomyelitis as a complication of umbilical artery cathOsteomyelitis as a complication of umbilical
eterization. Am f Dis Child 1977;131:142-4.

7 Ash JM, Gilday DL. The futility of bone scanning in neonatal Ash JM, Gilday DL. The futility of bone scanning in neonatal
osteomyelitis: concise communication. $\mathcal{J}$ Nucl Med 1980; 21:417-20.

8 Bergdhal S, Elinder D, Eriksson M. Treatment of neonatal osteomyelitis with cloxacillin in combination with fusidic acid. Scan $\mathcal{F}$ Infect Dis 1981;13:281-2.

9 Liddy N. Intravenous fusidic acid in the newborn. Lance $1973 ; \mathrm{i}: 621$.

10 Mollan RAB, Piggot J. Acute osteomyelitis in children Ұ Bone foint Surg 1977;54B:2-7. 